\title{
Correlation Between Numbers of Low Income Households and Urban Slums Expansion in Cimahi
}

\author{
ANITA VITRIANA \\ Badan Penelitian dan Pengembangan Daerah Provinsi Jawa Barat, Gedung BPKAD \\ Jl. Kawaluyaan Indah Raya No. 6 Kota Bandung, Indonesia \\ correspondence author: avitriana@yahoo.com
}

\begin{abstract}
Cimahi is one of the fast growing cities located next to Bandung City where both cities formed the urban centers of Bandung Metropolitan Area. Like other urban centers, Cimahi also faces difficulties in eradicating slums area, even though the government has been running physical improvement programs for slums area annually. The condition of the community is thought to correlates with the existence of slums. This study aims to examine how the numbers of low-income households in Cimahi are correlated with the slums area. The study is based on secondary data qualitative approach to be processed with simple linear regression. The results of the study show that the increase in numbers of low-income households have a significant effect on the expansion of slum areas. This research confirms that slums eradication will not be sustainable if it only relies on physical projects since it also requires comprehensive socio economic intervention as well as health education.
\end{abstract}

Keywords: low-income communities, slums area, comprehensive intervention

\section{Introduction}

Slums are one of the crucial problems faced by most developing countries. Urban-slums phenomenon has become a universal matter accompanying urban growth (Subasinghe, 2015). Slums are characterized by a very dense neighborhood, substandard housing conditions, lack of basic infrastructure, and poor sanitation (Goswami and Manna, 2013; Ballesteros, 2010). UNHabitat defined slum as a settlement in an urban area in which more than half of the inhabitants live in inadequate housing and lack of basic services (UN-Habitat, 2006). Millington \& Cleland (2017) stated that 30\% of South Asian urban residents live in slums. At present, nearly 1 million people live in slums and that number will increase twice by 2030 . In 2015 , there was 38,431 ha of slum area in Indonesia where 23,473 ha of which were in urban areas. Thus, the urbanslum area reaches $61 \%$ or greater than the total slums of rural areas (Rassanjani, 2018). Surprisingly, slum areas in Indonesia in 2019 has increased more than doubled or become 87,000 ha (A. Wicaksono, 2019).

Slums generally grow as a consequence of the needs of urban housing for low-income people who can't afford adequate housing facilities and services (Chetia, 2014). This phenomenon arises due to the dichotomy of high housing needs for city dwellers versus limited availability of land which ultimately leads to higher urban land prices. As a result, low-income urban communities have no choice but to live in urban slums.

One of the biggest contributors to urban-slums in Indonesia is the metropolitan area. Cimahi, which together with Bandung became the urban-center of Bandung Metropolitan Area, is one of the most rapidly growing urban areas in West Java that faces difficulties in eradicating slums. In 2007, there were 186 slum locations in Cimahi which contained 1,959 slum dwellings inhabited by 4,682 households (The Agency of Housing and Human Settlement of Cimahi, 2017). In 2011, based on Cimahi Mayor Decree

Received: 2020-03-28, Revised: 2020-05-05, Accepted: 2020-06-03. 
No. 648 concerning Location Determination of Slum Housing and Settlements, 12 slum areas spread over in 7 villages in Cimahi with a total of 165 ha or $4.09 \%$ of the Cimahi area. In 2013, it was detected that 15 slum locations spread across 10 urban villages with a total of $176.77 \mathrm{Ha}$ or $4.39 \%$ of the Cimahi area (The Local Government of Cimahi City, 2013). In 2017, slum areas have been reduced to $156.79 \mathrm{Ha}$ or $3.89 \%$ of the total area of Cimahi (The Agency of Housing and Human Settlement of Cimahi, 2017) along with the implementation of Kotaku Program (Cities Without Slums) which is one of the central government's priority programs in 2014-2019. In 2019, according to the end of Kotaku Program, the slums area in Cimahi remained $75.80 \mathrm{Ha}$ (Febriani, 2020). Figure 1 shows an image of slum area in one of urban villages in Cimahi.

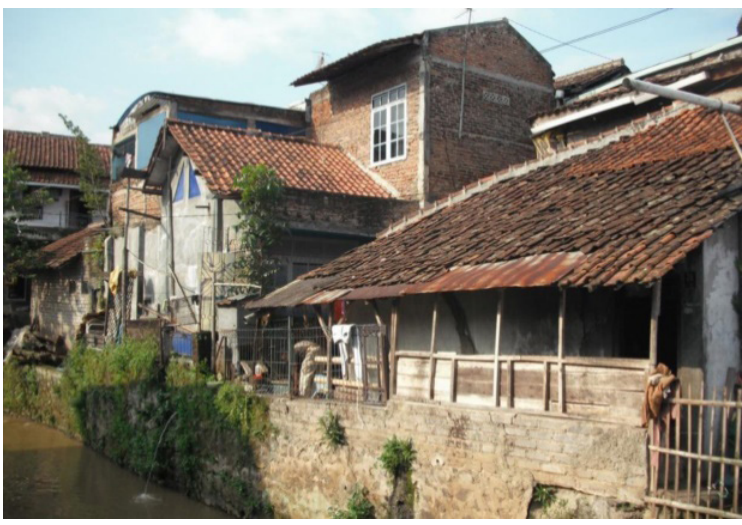

Figure 1. Slum Areas in Sukawargi, Cibabat Urban-Village, Cimahi Tengah Sub-District, Cimahi City

(Source: The Local Government of Cimahi, 2013)

The 2014-2019 National Medium term Development Plan stated that the central government would launch a program dealing with slums as one of the main achievement targets in the settlement infrastructure sector. According to the plan, the government has launched the 100-0-100 program, namely the movement of $100 \%$ access to safe drinking water, $0 \%$ slums, and $100 \%$ proper sanitation access. The slum indicators based on the Kotaku Program consist of seven plus one aspects, namely buildings, environmental roads, clean water supply and drinking, environmental drainage, wastewater management, waste management, fire safety, and public open space. Under this program, by the end of 2019, there should be no more slums in Indonesia.

The physical improvement of residential areas often assesses the reduction in numbers of slums. However, the sustainability of the physical quality of the slums still requires maintenance costs, which certainly requires the financial strength of the slum dwellers. The embryo of slums mostly started from individuals housing built on the land that has not been prepared and equipped with supporting infrastructure. These poor houses compounded with unorganized building arrangements have made the environment of slums much worsen. The weak economic conditions of society usually become one of the key factors of the formation of slums.

When referring to this issue, the presence of low-income urban communities naturally has a very significant correlation with the existence of slums. The existence of slums and low-income urban populations would persistently arise in line with the increase of the urban population. The government should anticipate the issue of urban-slums growth since the beginning to support the sustainability of the urban environment.

Some scholars have discussed issues about the correlation between numbers of low-income people and the existence of urbanslums. Resa, Saam, and Tarumun (2017); Andini (2013); Rahayu and D (2007); Suhaeni (2010); Sela (2016); Hariyanto (2007) and Chetia (2014) have explained about the strategies evaluations and handling policies of slums and informal communities. Vilar and Cartes (2016); Heston and Yusuf (2013); Bhatkal and Lucci (2015) have examined the relationship between slum upgrading and social capital development. Kamruzzaman and Hakim (2016); Isunju et al. (2011); Jha and Tripathi (2014) and Subasinghe (2015) have described the socio-economic conditions of slum dwellers. Meanwhile, Wihadanto, Barus, Achsani, \& Bratakusumah (2017) have assessed the level of slums.

But studies that specifically examine the correlation between numbers of low-income communities with the spatial expansion of urban-slums are still not many to find. Therefore, this study will examine a direct correlation between a large number of lowincome households and the expansion of slums in the urban village (kelurahan) in Cimahi to ensure a direct correlation between the two variables. Research that previews the correlation of low-income populations with the existence of urban-slums areas is important as an overview for the government, especially as an input for handling slum 
areas. In addition, this study will contribute to the debate on the relationship between the sustainability of the physical improvement program and the socio-economic conditions in the slum area.

\section{Research Methodology}

This research used a quantitative method. We obtain data through secondary sources of the 2017 Final Report of RP2KPKP (Final Report of Settlement Prevention and Improvement Plan for Urban-slums). This source describes the profile of urban-slums in Cimahi in terms of physical condition and demographic populations. The research examined the data with SPSS Statistics software in terms of simple linear regression analyses. The analysis is written by a descriptive explanatory approach.

This study used simple linear regression test by SPSS Statistic software to examine the effect of the existence of low-income households with the urban-slums areas. The statistical technique of simple linear regression analysis explores the relationship between an independent variable and a dependent variable. This variable acted as independent variables and would predict the area of the slum as the dependent variable. The score of the dependent variable was affected by the modification of the score of independent variables. The independent variable will predict the score of the dependent variable. In this research, the linearity between two variables determined the regression analysis. The test performed by a t-test or probability test value ( $p$-value) to measure the strength of a linear relationship between independent and dependent variables. The hypothesis of this research is as follows:

Ho: There is no significant correlation between the numbers of low-income households and the slum area (not meets the criteria of linearity).

Ha: There is a significant correlation between the numbers of low-income households and the slum area (meets the criteria of linearity).

The confidence intervals of $95 \%$ or $a=0.05$

This $p$-value determined the significance level of the equation. $\mathrm{Ha}$ is accepted and $\mathrm{Ho}$ is declined if the score of the p-value is less than the significant level. Vice versa, $\mathrm{Ha}$ is declined and $\mathrm{Ho}$ is accepted if the score of the $p$-value is greater than the significant level. The numbers of low-income households represented the independent variable and the slum area represented the dependent variable.

\section{Results and Discussion Profile of Slum Area in Cimahi}

Based on RP2KPKP report, there has been a significant decrease in the area of the urban-slums year by year, especially after Cimahi implemented the Kotaku program. The Government of Cimahi has carried out the determination of the slum baseline in detail since 2013. The local government has also determined the size of the slums area of $176.86 \mathrm{Ha}$ at the beginning of 2015. After the intervention of Kotaku (Cities without Slums) Program, there has been a decrease in slum areas.

In 2017, the Cimahi government updated the baseline data on slum areas and defined the number of $156.79 \mathrm{Ha}$. However, based on the results of the latest data, it is found that there was not only slum reduction at the predefined area, but also the emergence of the new slum at the previously undefined area. Thus, it was not surprising that the slum area tended to be static. This explanation can be seen in table 1 which compares the slum profile in each Urban Village in Cimahi.

Based on the comparison of the results of data mapping in 2013 and 2015, 11 locations have undergone a decrease in the slum area, although not all were significant. Only Rancabentang Village, Cibeurum, showed a significant reduction in the size of the slum area by more than 5 hectares. The table also revealed there was one location that had no change in the area of slum, two locations experienced the increase of slum area, and the addition of two new locations of slum which previously unidentified. The absence of slum decrease in Kampung Pojok did not mean there was no physical improvement program, but because of another slum spot has been identified during the baseline updating.

In terms of population, Cimahi citizen has increased by $25 \%$ since the establishment of the city in 2001. Based on RP2KPKP, the increase of slum areas in Cimahi in the period of 2011 to 2015 was $7 \%$ and the increased numbers of slum households have doubled in the last ten years (2007 to 2017). However, based on table 2, it was found that the composition of the low-income population living in slums is approximately as much as $37.51 \%$ or less than half of the total slum population in Cimahi. It indicated that many residents who came from upper social status also lived in the slums area. Table 2 shows 
Table 1

Distribution of Slum Areas in Cimahi

\begin{tabular}{lcc}
\hline Location of Slum Area & $\mathbf{2 0 1 3}$ & $\mathbf{2 0 1 7}$ \\
\hline Sukawargi, Cibabat, North Cimahi & 5.94 & 4.60 \\
Pojok, Setiamanah, Central Cimahi & 33.01 & 33.01 \\
Cisangkan, Padasuka, Central Cimahi & 21.26 & 18.82 \\
Rancabelut, Padasuka, Central Cimahi & 7.30 & 3.46 \\
Rancacangkuang, Padasuka, Central Cimahi & 15.66 & 11.86 \\
Kalidam, Karang Mekar, Central Cimahi & 3.04 & 0 \\
Babakan Kidul, Cigugur Tengah, Central Cimahi & 22.66 & 21.26 \\
Margaluyu, Cimahi, Central Cimahi & 2.51 & 3.15 \\
Rancabentang, Cibeureum, South Cimahi & 27.08 & 22.4 \\
Kihapit, Leuwigajah, South Cimahi & 11.86 & 11.96 \\
Hujung, Utama, South Cimahi & 8.16 & 6.42 \\
Cibodas Campaka, Utama, South Cimahi & 6.76 & 5.75 \\
Cikendal, Melong, South Cimahi & 3.18 & 12.43 \\
Sukagalih, Melong, South Cimahi & 0 & 1.67 \\
RW 12, Leuwigajah, South Cimahi & 6.03 & 0 \\
RW 14, Leuwigajah, South Cimahi & 2.41 & 0 \\
Sum & $\mathbf{1 7 6 . 8 6}$ & $\mathbf{1 5 6 . 7 9}$ \\
\hline
\end{tabular}

Table 2

Profile of Urban Slums Population in Cimahi

\begin{tabular}{lccc}
\hline \multicolumn{1}{c}{ Location of Slum Area } & $\begin{array}{c}\text { Ho u s e - } \\
\text { holds }\end{array}$ & $\begin{array}{c}\text { Low Income } \\
\text { House holds }\end{array}$ & $\begin{array}{c}\text { Low-income House } \\
\text { holds (\%) }\end{array}$ \\
\hline Sukawargi, Cibabat, North Cimahi & 448 & 177 & 39.51 \\
Pojok, Setiamanah, Central Cimahi & 1884 & 679 & 36.04 \\
Cisangkan, Padasuka, Central Cimahi & 1152 & 443 & 38.45 \\
Rancabelut, Padasuka, Central Cimahi & 279 & 79 & 28.32 \\
Rancacangkuang, Padasuka, Central Cimahi & 602 & 299 & 49.67 \\
Kalidam, Karang Mekar, Central Cimahi & 332 & 92 & 27.71 \\
Babakan Kidul, Cigugur Tengah, Central Cimahi & 1879 & 547 & 29.11 \\
Margaluyu, Cimahi, Central Cimahi & 599 & 324 & 54.09 \\
Rancabentang, Cibeureum, South Cimahi & 1685 & 574 & 34.07 \\
Kihapit, Leuwigajah, South Cimahi & 1613 & 485 & 30.07 \\
Hujung, Utama, South Cimahi & 748 & 433 & 57.89 \\
Cibodas Campaka, Utama, South Cimahi & 488 & 122 & 25.00 \\
Cikendal, Melong, South Cimahi & 1693 & 770 & 45.48 \\
Sukagalih, Melong, South Cimahi & 187 & 73 & 39.04 \\
Sum & $\mathbf{1 3 5 8 9}$ & $\mathbf{5 0 9 7}$ & $\mathbf{3 7 . 5 1}$ \\
\hline
\end{tabular}

Source: The Agency of Housing and Human Settlement of Cimahi (2017)

that 12 out of 14 slum areas were inhabited by more than half of upper-income households. There were only 2 slum locations that had more than $50 \%$ of the population of low- income households. Table 2 shows the profile of the low-income population living in the slums of Cimahi. 


\section{Statistical Test on the Correlation between the Numbers of Low Income Households and the Slum Area in Cimahi}

Table 3 describes the results of a statistical test between numbers of lowincome households and the slum area in Cimahi. Table of Model Summary shows the correlation value $(R)$ between those variables is 0.755 . The determination coefficient value of this correlation (R2) is 0.570 . It means the variable of low-income households has a contribution effect on the variable of slum area for $57 \%$. Other variables correlate the rest. The scores indicate the relationship between these two variables is quite strong.

Furthermore, the ANOVA test has determined the F-count value of 14.571 with a score of the $p$-value of 0.003 or less than $a$. It means the regression model is linear and the equation can be accepted to predict the variable of the Cimahi slum area. The model also confirms that the numbers of low-income households have a significant correlation in slum areas.

The Coefficients Output Table shows the constants score is 0.082 . The scores of regression coefficients value of 0.031 show that the addition of each low-income households will contribute to the increase of 0.031 ha of the slum area. From this Anova Table, we can define the regression equation as $Y=0.082+0.031 \mathrm{X}$. This regression equation indicates that numbers of lowincome households correlate with an increase of slum area with quite a strong degree of correlation.

The equation indicates the existence of low income households strongly contributed to the expansion of the slums area. Even though the proportion of low-income households who live in slum areas not even half of the

Table 3

Simple Linear Regression Test on Numbers of Low-income Households and Slum Area in Cimahi

Variables Entered/Removed

\begin{tabular}{llll}
\hline Model & Variables Entered & Variables Removed & Method \\
\hline 1 & The Number of Low-Income Households & . & Enter \\
\hline
\end{tabular}

a. Dependent Variable: Area of Slum

b. All requested variables entered.

Model Summary

\begin{tabular}{lllll}
\hline Model & \multicolumn{1}{c}{$\mathbf{R}$} & R Square & Adjusted R Square & Std. Error of the Estimate \\
\hline 1 & $.755 a$ & .570 & .531 & 6.45337 \\
\hline a. Predictors: (Constant), The Number of Low-Income Households &
\end{tabular}

\begin{tabular}{|c|c|c|c|c|c|c|}
\hline & Model & Sum of Squares & df & Mean Square & $\mathbf{F}$ & Sig. \\
\hline \multirow[t]{3}{*}{1} & Regression & 606.814 & 1 & 606.814 & 14.571 & $.003 b$ \\
\hline & Residual & 458.106 & 11 & 41.646 & & \\
\hline & Total & 1064.920 & 12 & & & \\
\hline
\end{tabular}
a. Dependent Variable: Area of Slum
b. Predictors: (Constant), The Number of Low-Income Households

Coefficients

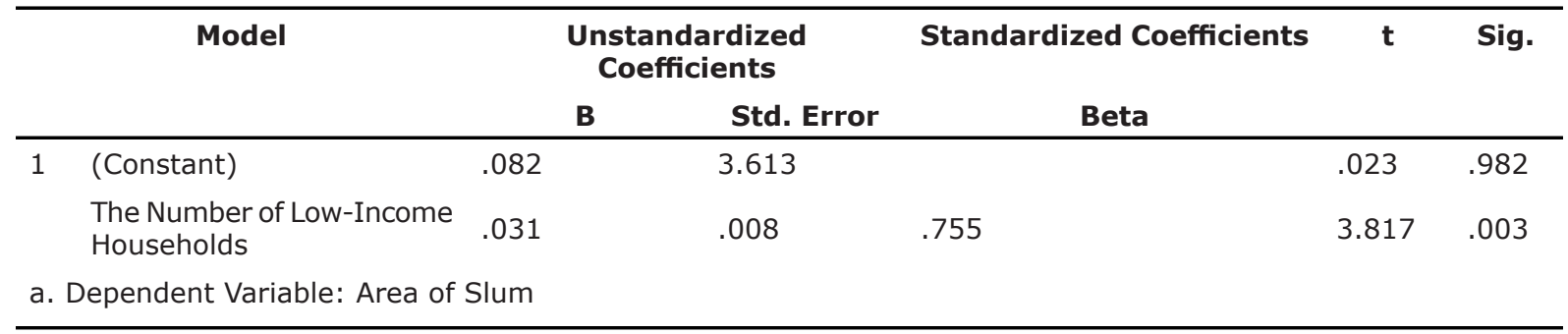


population, the presence of them has a significant effect on the expansion of the slums area in Cimahi. The area of urban slums continues to grow along with the increasing number of urban low-income households. It indicates that slums are the manifestation of the characteristics of urban poverty. The correlation of low-income communities with the existence of slums shows that mere physical improvements approach cannot solely solve the problem of urban slums.

The tight relationship between socioeconomic conditions of the community with the existence of slum is also in line with Lucci, Bhatkal, \& Khan (2018) whose stated it was difficult to discuss poverty without focusing on slums. Mathur (2014) also stated that slums were the most visible manifestation of poverty in Asia and elsewhere in developing regions. Those two studies showed there was a high correlation between poverty and slums. When numbers of poor people increases, there is a potential slum enlargement in the area and vice versa.

The condition between the low-income population and the area of urban-slums in Cimahi goes in line with the premise. In 2013 the slum in Cimahi was defined at 176, $78 \mathrm{Ha}$, and at the end of 2019, it has decreased to $75.80 \mathrm{Ha}$. Along with that, there has been a decline in the numbers of poor people in Cimahi between 2013-2018. In 2013, the number of poor people in Cimahi was 32.30 thousand people or as much as $5.63 \%$ of the total population. In 2018, it decreased to 29.94 thousand or $4.94 \%$ of the total population. It indicates numbers of poor people in Cimahi declined only as much as $0.69 \%$ in 5 years (BPS Cimahi, 2019).

However, the decline in numbers of poor people at the national level was not in line with the reduction in the total area of the national slums. Based on September 2014 BPS data, the number of poor people was 27.73 million people or $11.96 \%$, while in March 2019, number of poor people was 25.14 million or $9.41 \%$ (Kusnandar, 2019). The decrease in number of poor people in the national level is not in line with the reduction in the slum area because there is still an increase in slum area more than doubled in the period of 2014 to 2019 (P. E. Wicaksono, 2017). This peculiarity might lead to allegations that more and more middle-class people live in the slum area or the possibilities that low-income households who live in the slum area have improved their socio-economic status.

\section{Comprehensive Handling between Physical Improvement Programs of Slum Areas and Strengthening the Socio Economic Capacity of Low Income Communities}

In the international context, Duflo, Galiani, and Mobarak (2012) revealed that almost a billion people (more than onethird of the urban population) primarily lived in slums in the developing countries. The characteristics of the people who lived in slums were overcrowding, high levels of unemployment, or underemployment with widespread insecurity. As Mathur (2014) described slums were the most visible manifestation of poverty in Asia as it is in the other developing regions. In 2017, numbers of low-income populations in urban Indonesia reached 10.49 with the area of the slum of $38.431 \mathrm{Ha}$ and housing backlog of 7.6 million houses. The estimates of urban population numbers in 2020 will reach $60 \%$ (P. E. Wicaksono, 2017).

Considering the slum problem is closely related to poverty (Lucci et al., 2018), it is very important to have an integrated program between physical improvement and the socio-economic enhancement of the community who live in the slum areas. The urgency of integrated socio-economic and physical programs shows the importance of the government's role to assist the community so that they can maintain a healthier environmental condition along with efforts to foster social and economic conditions. It also confirms the importance of community concern and participation to maintain a good environment. One way to improve the community's ability to maintain the sustainability of their settlements is through the strategy of creating social capital to build networks among the people (Vilar \& Cartes, 2016). Physical upgrading that is not followed by the improvement in the socioeconomic capacity of slum dwellers would only last temporary because physical attribute requires maintenance if not, it will return to its basic condition. As it is explained by Minnery et al. (2013) that the big challenge for low-income people is to set aside some of the income to maintain the sustainability of slum improvements because it also requires community sustainability to escape from poverty. For this reason, one of the important things formulated to solve the slum problem is that the government has to make a comprehensive program to eradicate slum with the multi sectors program to enhance 
the physical-social-economic capabilities of low-income communities. The success of social strengthening on alleviating urbanslums is more or less highly dependent on the role of government in increasing community capacity (Heston \& Yusuf, 2013). In this case, the government program cannot run alone without the participation of the community. No matter how good the government program to deal with slums, it will be difficult to alleviate the slum area if the mindset of the community is still reluctant to maintain environmental sustainability. Slum eradication programs require a strong commitment from all of the parties, especially the government and the community itself.

The Kotaku Program aims to increase access to basic infrastructure and services in urban slums to support the realization of habitable, productive and sustainable urban settlements. The program has two purposes. First, to improve public access to infrastructure and service facilities in urbanslums. Second, to improve the social-economic status of households in urban-slums as well as to intensify the collaboration between the community and local governments to preserve the sustainability of the area. The Kotaku Program has launched one strategic program for handling slum areas through a collaboration platform by increasing the role of local governments and community participation in the context of accelerating government policies so that in 2019 all Indonesian cities will be free of slums. The Kotaku program simultaneously improves community access to settlement infrastructure, strengthens the capacity of local governments to develop collaboration with stakeholders, and improves the level of community welfare through the development of sustainable livelihoods. The government has launched the Kotaku program along with the Community-Based Livelihoods Improvement Program (PPMK) through the development of Community Self-Help Group businesses since 2012 in the framework of the PNPM program to implement the improvement of community welfare.

The PPMK program aims to overcome the problem of poverty, carried out through the provision of microloans to communities with productive businesses or potentially developing. Some programs have started to run effectively, but there are still some obstacles in the implementation. The constraints include the unoptimal socialization and inaccurate calculating between given capital versus the ability of community members to repay the loans. The PPMK program still needs to improve the human resources, communication and public awareness, and monitoring by the facilitator as government's representative (Kirana, 2015), as well as social capital conditions, and the quality of financial resources (Dianti, 2017).

This community self-improvement program launched by PPMK is in line with the concept of Muhammad Yunus in improving the socio-economic conditions of the poor people of Bangladesh. Nurhayati (2016) stated that the strength of Muhammad Yunus program is known as the social entrepreneurship scheme through the creation of a micro-credit system with the concept of community guarantee. By applying the concept of community strengthening, Muhammad Yunus has succeeded in increasing the empowerment of the poor in Bangladesh to improve socioeconomic conditions as well as their quality of life.

The key success of non-physical assistance in handling slum cannot only focus on improving the socio-economic conditions of the community. The government also has to provide good educating regarding the importance of healthy behavior and environmental stewardship to the local community. These two things have to go hand in hand. The slums will be difficult to eradicate even though the government has launched several brilliant programs if the community does not understand the importance of taking care of their neighborhood sustainability.

\section{Conclusions}

The study shows that the increase of low-income communities correlates with the expansion of the slum area in Cimahi. Lowincome households variables have a significant correlation with the existence of slums in Cimahi, which is 57\%. The results of the study affirm that the slum handling program cannot only count on physical improvement, but it needs a comprehensive program that can also improve the socio-economic quality of the community. Thus, low-income people will have the strength and the ability to escape from poverty as well as they can sustain to live in a good quality of the urban neighborhoods. The government has to develop a more long term and sustainable self-improvement system to intensify the low-income people's socio-economy empowerment along with the enhancement of health comprehension 
capacity that provides possibilities for them to maintain their quality of the environment by themselves. At that point, the government can act as a facilitator. The sustainability of good physical environment quality should always be maintained and it requires a strong cooperation between the government and the community itself.

\section{Acknowledgement}

The researchers would like to thank The Regional Agency for Research and Development, West Java (Badan Penelitian dan Pengembangan Daerah Jawa Barat) for all of the support and The Agency of Housing and Settlement of Cimahi for the data support.

\section{References}

Andini, I. (2013). Sikap dan Peran Pemerintah Kota Surabaya Terhadap Perbaikan Daerah Kumuh di Kelurahan Tanah Kalikedinding Kota Surabaya. Kebijakan Dan Manajemen Publik, 1(1), 36-47.

Ballesteros, M. M. (2010). Linking poverty and the environment : evidence from slums in Philippine cities. Discussion Paper. Makati. Retrieved from http://dirp4.pids.gov.ph/ ris/dps/pidsdps1033.pdf

Bhatkal, T., \& Lucci, P. (2015, June). Community-Driven Development In The Slums: Thailand's Experience' With the Baan Mankong Housing Programme, The Role of The Community. Overseas Development Institute, (June), 8.

BPS Cimahi. (2019). Inkesra (Indikator Kesejahteraan Rakyat) Kota Cimahi) 2019. (E. Syahriza \& T. T. Sulistiawati, Eds.) (1st ed.). Cimahi: Badan Pusat Statistik Kota Cimahi. Retrieved from https://cimahikota.bps.go.id/publicatio n/2019/12/24/1edffdba3b0a4258a2d96 ce2/indikator-kesejahteraan-rakyat-kotacimahi-2019.html

Chetia, P. (2014). Conditions and perceptions of the urban poor. IOSR Journal Of Humanities And Social Science (IOSRJHSS), 19(7), 48. https://doi.org/e-ISSN: 2279-0837, p-ISSN: 2279-0845.

Dianti, I. A. (2017). Efektivitas Program Peningkatan Penghidupan Masyarakat Berbasis Komunitas (PPMK) dalam Meningkatkan Pendapatan Anggota Kelompok Swadaya (KSM): Studi Kasus LKM Margodadi Jaya Kecamatan Metro Selatan Kota Metro Lampung. Universitas Lampung. Retrieved from http://digilib.
unila.ac.id/28288/3/Skripsi Tanpa Bab Pembahasan.pdf

Duflo, E., Galiani, S., \& Mobarak, M. (2012). Improving Access to Urban Services for the Poor: (J. Shah, Ed.). Cambridge, Massachusetts. Retrieved from https://www.google.co.id/url?sa $=\mathrm{t}$ \&rct $=j \& q=\&$ esrc $=s \&$ source $=w e b \& c d=1 \&$ $\mathrm{cad}=$ rja\&uact $=8 \&$ ved $=0$ ahUKEwjRo66P5 LLVAhXD6Y8KHWX0AIgQFggmMAA\&url= https\%3A\%2F\%2Fwww.povertyactionlab. org $\% 2$ Fpublication $\% 2$ Fimprovinga c c e s s - u r b a n - s e r vicespoor\&usg=AFQjCNGUdrYXzcOFHQ_5Mo3Rgj-C

Febriani, R. N. (2020). Kawasan Kumuh di Kota Cimahi Capai 75,8 Hektare. Retrieved February 15, 2020, from https://www. pikiran-rakyat.com/bandung-raya/pr01323629/kawasan-kumuh-di-kotacimahi-capai-758-hektare

Goswami, S., \& Manna, S. (2013). Urban Poor Living in Slums: A Case Study of Raipur City in India. Global Journal of HUMAN SOCIAL SCIENCE Sociology \& Culture, 13(4), 15. Retrieved from https:// globaljournals.org/GJHSS_Volume13/3Urban-Poor-Living-in-Slums-A-CaseStudy.pdf

Hariyanto, A. (2007). Strategi Penanganan Kawasan Kumuh sebagai Upaya Menciptakan Lingkungan Perumahan dan Permukiman yang Sehat (Strategy for Handling Slums as an Effort to Create a Healthy Housing and Settlement Environment (Case Study: Pangkalpinang). Jurnal PWK Unisba, 7(2), 17. Retrieved from https://www.google.co.id/url?sa $=t \& r c t=j \& q=\& e s r c=s \&$ source $=$ web\&cd $=2 \& \mathrm{cad}=\mathrm{rja} \&$ uact $=8 \& \mathrm{ved}=0$ ahUKEwja ka3o3rLVAhXMPY8KHVt8BQsQFggwMA E\&url =http $\% 3 \mathrm{~A} \% 2 \mathrm{~F} \% 2 \mathrm{Fpuslit2}$. petra. ac.id\%2Fejournal\%2Findex.php $\% 2$ Fpwk $\% 2$ Farticle\%2Fdownload\%2F17761\%2F1 7725\&usg =AFQjCNHNtz2AW6m6b4CRHT Heston, Y. P., \& Yusuf, A. (2013). Penguatan Kemampuan Sosial Pada Penataan Kawasan Kumuh Perkotaan (Studi Kasus Kelurahan Cigugur Tengah Cimahi): Social Enrichment In Slum Urban Areas Rearrangement Program. Tata Loka, 15(3), 208. Retrieved from http:// ejournal2.undip.ac.id/index.php/tataloka/ article/viewFile/277/194

Isunju, J. B., Schwartz, K., Schouten, M. A., Johnson, W. P., \& van Dijk, M. P. (2011). Socio-economic aspects of improved sanitation in slums: A review. Public Health, 125(6), 368-376. https://doi. 
org/10.1016/j.puhe.2011.03.008

Jha, D. K., \& Tripathi, V. K. (2014). Quality of life in slums of varanasi city: A comparative study. Transactions of the Institute of Indian Geographers, 36(2), 171-183.

Kamruzzaman, M., \& Hakim, M. A. (2016). Socio-economic Status of Slum Dwellers : An Empirical Study on the Capital City of Bangladesh. American Journal of Business and Society, 1(2), 13-18.

Kirana, M. P. (2015). Efektivitas Pelaksanaan Peningkatan Penghidupan Masyarakat Berbasis Komunitas ( PPMK) dalam Program Nasional Pemberdayaan Masyarakat Mandiri Perkotaan di Kelurahan Karang Berombak Kecamatan Medan Barat. Universitas Sumatera Utara. Retrieved from http://repositori.usu.ac.id/ handle/123456789/19469

Kusnandar, V. B. (2019). Pemerintah Jokowi Periode I: Penduduk Miskin Berkurang 2,6 Juta Jiwa. Retrieved February 16, 2020, from https://databoks.katadata. co.id/datapublish/2019/10/17/5-tahunpertama-kepemimpinan-jokowi-angkakemiskinan-turun-155-bps

Lucci, P., Bhatkal, T., \& Khan, A. (2018). Are we underestimating urban poverty? World Development, 103, 298. https:// doi.org/10.1016/j.worlddev.2017.10.022

Mathur, O. P. (2014). Urban Poverty in Asia. (A. Bauer, J. Brömmelhörster, \& F. Steinberg, Eds.). Mandaluyong City: Asian Development Bank. Retrieved from https://www.adb.org/sites/default/files/ publication/59778/urban-poverty-asia.pdf

Millington, K. A., \& Cleland, J. (2017). Counting people and making people count : Implications of future population change for sustainable development. K4D Helpdesk Report. Liverpool, UK. Retrieved from https://opendocs. ids.ac.uk/opendocs/bitstream/ handle/20.500.12413/13015/153 Implications of future population change for sustainable development. pdf? sequence $=337$ \&isAllowed $=y$

Minnery, J., Argo, T., Winarso, H., Hau, D., Veneracion, C. C., Forbes, D., \& Childs, I. (2013). Slum upgrading and urban governance: Case studies in three South East Asian cities. Habitat International, 39, 168. https://doi.org/10.1016/j. habitatint.2012.12.002

Nurhayati. (2016). Social Entrepreneurship Muhammad Yunus "Grameen Bank "Abstrak Pendahuluan Istilah social entrepreneurship menjadi topik menarik dalam perbincangan di. Jurnal Bisnis,
Manajemen \& Perbankan, 2(12016), 3148. https://doi.org/P-ISSN : 2338-4409

Rahayu, M. J., \& D, R. (2007). Strategi Perencanaan Pembangunan Permukiman Kumuh : Kasus Permukiman Bantaran Sungai Bengawan Solo, Kelurahan Pucangsawit, Surakarta. Gema Teknik, $X$ (Januari), 89-96.

Rassanjani, S. (2018). Indonesian Housing Policy and Sustainable Development Goals (SDGs). Otoritas : Jurnal IImu Pemerintahan, 8(1), 44-55. https://doi. org/10.26618/ojip.v8i1.760

Resa, A. M., Saam, Z., \& Tarumun, S. (2017). Strategi Penataan Kawasan Permukiman Kumuh Perkotaan Kampung Bandar Kota Pekanbaru. Dinamika Lingkungan Indonesia, 2(2), 117.

Sela, R. L. E. (2016). Perencanaan Pencegahan dan Peningkatan Kualitas Permukiman Kumuh Perkotaan dengan Pendekatan Compact City Strategy Koridor Lintas Tengah di Kabupaten Lampung Tengah. In G. A. Susilo, P. H. Pramitasari, G. A. Putra, B. T. Ujianto, \& Hamka (Eds.), Temu IImiah IPLBI 2016 (pp. G085-G092). Malang: IPLBI. Retrieved from https:// www.google.co.id/url?sa $=t \& r c t=j \& q=\& e$ $\mathrm{src}=\mathrm{s} \&$ source $=$ web $\& \mathrm{~cd}=2 \& \mathrm{cad}=\mathrm{rja} \& u a c t$ $=8 \&$ ved $=0$ ahUKEwjKsJGj3bLVAhUDPo8K HfMLC6YQFggsMAE\&url=http $\% 3 A \% 2 F \% 2$ Ftemuilmiah.iplbi.or.id\%2Fwp-content\%2 Fuploads\%2F2016\%2F12\%2FIPLBI2016G-085-092-Perencanaan-Pencegahandan-Penin

Subasinghe, W. (2015). Quality of Life Study on Slum Dwellers ( With Special Reference to Sri Lanka ). International Journal of Scientific Research and Innovative Technology, 2(3), 36-65.

Suhaeni, H. (2010). Tipologi Kawasan Perumahan dengan Kepadatan Penduduk Tinggi dan Penanganannya. Jurnal Permukiman, 5(3), 119. Retrieved from https://www.google.co.id/url?s $a=t \& r c t=j \& q=\& e s r c=s \& s o u r c e=w e b$ $\& c d=1 \& c a d=r j a \& u a c t=8 \&$ ved $=0$ ahU KEwj6kZiR3LLVAhXLN48KHWSmDZE QFggmMAA\&url=http \%3A\%2F\%2F2 22.124.202.172\%2Fuploads\%2Fserv ices\%2Finfopublik20131119125301. p d f \& u s g = A F Q j C N GX D V i4V6ezA0TE20IDqk3_-O4IA

The Agency of Housing and Human Settlement of Cimahi. (2017). Final Report of Settlement Prevention and Improvement Plan for Urban Slums (RP2KP-KP) Cimahi City. Cimahi.

The Local Government of Cimahi City. (2013). 
Profile of Slum Settlements in Cimahi City. Cimahi.

UN-Habitat. (2006). State of The World's Cities 2006/7. (R. Warah, Ed.) (1st ed.). London: Earthscan. Retrieved from https://www.google.com/url?sa $=$ t\&rct $=$ j $\& q=\& e s r c=s \&$ source $=$ web $\& c d=3 \& c a d=r j$ a\&uact $=8 \&$ ved $=2$ ahUKEwjN0cC6s6bdAh WSWysKHZ-fBUwQFjACegQICBAC\&url=h ttp\%3A\%2F\%2Fmirror.unhabitat.org\%2F pmss\%2FgetElectronicVersion.aspx\%3Fn r\%3D2101\%26alt\%3D1\&usg=AOvVaw1v Etru8byWNCswm9MnDEH

Vilar, K., \& Cartes, I. (2016). Urban Design and Social Capital in Slums. Case Study: Moravia's Neighborhood, Medellin, 20042014. Procedia - Social and Behavioral Sciences, 216(October 2015), 66. https:// doi.org/10.1016/j.sbspro.2015.12.008

Wicaksono, A. (2019). Kawasan Kumuh
Indonesia Meluas Dua Kali Lipat. Retrieved February 15, 2020, from https://www.cnnindonesia.com/ nasional/20190903212554-20-427289/ kawasan-kumuh-indonesia-meluas-duakali-lipat

Wicaksono, P. E. (2017). 90 Persen Kawasan Kumuh di RI Belum Ada Perbaikan. Retrieved February 15, 2020, from https://www.liputan6.com/bisnis/ read/3083165/90-persen-kawasankumuh-di-ri-belum-ada-perbaikan

Wihadanto, A., Barus, B., Achsani, N. A., \& Bratakusumah, D. S. (2017). Analisis Karakteristik dan Penilaian Tingkat Kekumuhan Kawasan Permukiman ' Kampung Braga' - Kota Bandung. Journal of Regional and Rural Development Planning, 1(2), 132-144. 